\title{
ANALISIS USAHA BUDIDAYA IKAN NILA (Oreochromis niloticus) DI KELURAHAN REWARANGGA SELATAN, KECAMATAN ENDE TIMUR, KABUPATEN ENDE
}

\author{
Barnabas Pablo Puente Wini Bhokaleba ${ }^{1}$, Felicia Agnes Mengi ${ }^{2}$ \\ ${ }^{1}$ Dosen Program Studi Manajemen Sumberdaya Perairan, Universitas Nusa Nipa, Maumere, \\ Indonesia \\ ${ }^{2}$ Mahasiswa Program Studi Manajemen Sumberdaya Perairan, Universitas Nusa Nipa, Maumere, \\ Indonesia, \\ Email: bebbapablo@gmail.com¹ feliciamengi@yahoo.co.id ${ }^{2}$
}

Citasi: Bhokaleba, B. P. P. W., \& Mengi., F.A. (2019). Analisis Usaha Budidaya Ikan Nila (Oreochromis Niloticus) Di Kelurahan Rewarangga Selatan, Kecamatan Ende Timur, Kabupaten Ende. Mangifera Edu volume 3 (2): 122-132.

\begin{abstract}
ABSTRAK
Peningkatan jumlah penduduk setiap tahun di Kabupaten Ende mendorong peningkatan kebutuhan ikan konsumsi. Permintaan ikan yang sangat tinggi ditunjukan dengan adanya pasokan ikan dari luar kabupaten, terutama dari Kabupaten Flores Timur dan Kabupaten Sikka. Salah satu upaya alternatif dengan melakukan usaha budidaya ikan air tawar. Aktivitas budidaya ikan Nila di Kelurahan Rewarangga Selatan, Kecamatan Ende Timur dilakukan dengan pengetahuan dan teknologi sederhana. Tujuan dari penelitian ini adalah menganalisis usaha jangka pendek dan jangka panjang usaha budidaya ikan Nila. Penelitian survei dengan teknik purposive sampling untuk memilih secara pasti suatu tempat penelitian dan teknik total sampling atau sensus untuk penentuan responden. Dalam penelitian ini, jumlah responden sebanyak 5 orang sebagai pemilik unit usaha budidaya ikan Nila. Berdasarkan hasil analisis, usaha budidaya ikan Nila (Oreochromis niloticus) di Kelurahan Rewarangga Selatan, memberikan keuntungan rata-rata sebesar Rp 61.192.400 per tahun dengan Imbangan Penerimaan dan Biaya $(R / C)$ sebesar 2,38 dan waktu yang diperlukan untuk pengembalian dana yang diinvestasikan (PP) selama 0,49 tahun. Kemampuan dari modal untuk menghasilkan keuntungan bersih (ROI) sebesar $203 \%$. Usaha Budidaya Ikan Nila ini merupakan usaha yang layak dikembangkan karena memiliki nilai NPV > 0 yaitu sebesar Rp 161.185.453, nilai IRR < tingkat suku bunga yaitu sebesar $2,02 \%$ dan nilai Net $B / C>1$ sebesar 6,35.
\end{abstract}

Kata kunci: ikan nila, budidaya, analisis usaha, rewarangga selatan

\section{ABSTRACT}

Increasing the number of people in each year in Ende District encourages increased consumption of fish. A highest fish demand is indicated by the supply of fish from outside district, especially from East Flores and Sikka districts. One of the alternative efforts is by conducting freshwater fish farming. Nila fish cultivation activity in South Rewarangga Village of East Ende Districtis applied by using simple knowledge and technology. The aim of this research is to analyze the short-term and long-term business of tilapia fish farming. Survey research used in this research use purposive sampling technique to select definitively a research site and total sampling technique or census for respondent determination. In this 
research, the number of respondents as many as 5 people as the owner of Nila fish cultivation business. Based on the results of the analysis, the fish cultivation business of Tilapia (Oreochromis niloticus) in South Rewarangga Village gives an average profit of $R p$ 61,194,000 per year with Revenue and Cost $(R / C) 2.38$ and the time required for return funds invested (PP) for 0.49 years. The ability of capital to generate net profit (ROI) of $203 \%$. Tilapia Farming Business is a worthy effort to be developed because it has a value of $N P V>0$ which is $R p 161.185 .453$, IRR value <interest rate of $2.02 \%$ and $N e t B / C$ value > 1 of 6.35 .

\section{Keywords: tilapia, cultivation, business analysis, south rewarangga}

\section{PENDAHULUAN}

Stok ikan di wilayah perairan laut Kabupaten Ende dalam satu dekade terakhir mengalami penurunan disebabkan oleh penangkapan ikan tidak ramah lingkungan menggunakan bahan peledak yang berlangsung secara terus menerus. Aktivitas ini sering dilakukan nelayan karena kurang kesadaran masyarakat sehingga berdampak terhadap menurunnya kesejahteraan nelayan.

Sumberdaya ikan bersifat terbuka untuk dimanfaatkan oleh siapa saja dan dikategorikan sebagai sumberdaya yang dapat pulih, namun seringkali muncul pertanyaan seberapa besarkah sumberdaya yang dapat dimanfaatkan tanpa harus menimbulkan dampak negatif di kemudian hari. Keberlanjutan menjadi kata kunci dalam pembangunan perikanan yang diharapkan dapat memperbaiki kondisi sumberdaya serta kesejahteraan masyarakat perikanan (Fauzi dan Anna, 2005).

Peningkatan jumlah penduduk setiap tahun di Kabupaten Ende mendorong peningkatan kebutuhan ikan konsumsi. Masyarakat Kabupaten Ende memiliki tingkat konsumsi ikan yang cukup tinggi dimana setiap keluarga memiliki kebiasaan dan cara berpikir bahwa "tidak lengkap jika makan tanpa ikan", sekalipun ada lauk pengganti. Permintaan ikan yang sangat tinggi ditunjukkan dengan adanya pasokan ikan dari luar kabupaten, terutama dari Kabupaten Flores Timur dan Kabupaten Sikka. Oleh karena itu, upaya alternatif dengan melakukan usaha budidaya ikan air tawar. Meriza (2008) menjelaskan bahwa terlepas dari berbagai permasalahan dalam usaha budidaya yaitu adanya kegagalan dalam pembesaran ikan di air tawar, salah satunya pembudidayaan ikan Nila karena hingga saat ini komoditas ikan Nila masih merupakan pilihan utama untuk dibudidayakan oleh pembudidaya terutama pembudidaya sederhana.

Menurut Darseno (2010), permintaan akan ikan Nila di pasaran tidak kalah dari ikan air laut, dan banyak industri-industri yang bergerak di bidang perikanan memanfaatkan ikan 
Nila sebagai bahan utama dalam menghasilkan produk, misalnya Nila Presto dan Nila Tanpa Tulang.

Potensi budidaya perikanan tawar di Kabupaten Ende ditunjukkan dengan adanya aktivitas budidaya ikan Lele, ikan Nila, dan ikan Mas. Berdasarkan data BPS Kabupaten Ende (2016), permintaan ikan air tawar di Kabupaten Ende terus meningkat ditandai dengan produksi ikan air tawar mencapai angka tertinggi yaitu 31 ton pada tahun 2015. Sebagian besar produksinya berasal dari komoditas ikan Nila. Komoditas ini sangat digemari karena harga jual terjangkau, mudah dikembangkan dan rasanya gurih. Namun, produksi ikan Nila ini juga sangat tergantung dari teknologi budidaya yang digunakan (Murtidjo, 2007).

Menurut Nugroho (2007), teknologi usaha budidaya ikan Nila dibagi dalam tiga tingkat yaitu sistem ekstensif (teknologi sederhana), semi intensif (teknologi madya) dan intensif (teknologi maju). Aktivitas usaha budidaya ikan Nila sendiri telah lama dilakukan oleh pembudidaya Kabupaten Ende dengan pengetahuan dan teknologi sederhana. Menurut Rachmatun (2011), keterbatasan pengetahuan dan teknologi budidaya umumnya disebabkan karena terbatasnya jumlah dan kapasitas tenaga pendamping, putusnya koordinasi instansi yang mensosialisasikan setiap teknologi baru yang dihasilkan, dan rasa takut yang dimiliki pembudidaya untuk menerapkan teknologi baru di tempat usahanya. Kelurahan Rewarangga Selatan merupakan salah satu tempat usaha budidaya ikan Nila karena mudah dikembangkan dan harga jualnya terjangkau.

Sasaran akhir dari suatu aktivitas usaha budidaya ikan Nila di Kabupaten Ende, bukan hanya pada produksi, tetapi juga keuntungan. Sejauh ini belum ada penelitian mengenai analisis usaha budidaya ikan Nila, sehingga belum dapat diketahui berapa besar modal yang dibutuhkan, berapa biaya operasional, dan berapa keuntungan yang diperoleh dalam satu siklus atau periode budidaya. Berdasarkan latar belakang tersebut, maka perlu dilakukan analisis usaha jangka pendek dan analisis kriteria investasi usaha jangka panjang budidaya ikan nila di Kelurahan Rewarangga Selatan, Kecamatan Ende Timur, Kabupaten Ende.

\section{METODE PENELITIAN}

Bagian metode penelitian ini menguraikan langkah-langkah penyelesaian masalah. Uraikan dengan jelas prosedur penelitian yang dilakukan.

Metode yang dipilih agar disesuaikan dengan jenis penelitiannya. Sebagai contoh jika penelitian eksperimen maka desain penelitian, pengambilan populasi dan sampel serta prosedur pelaksanaan penelitian ditulis secara jelas dan sesuai dengan penelitian eksperimen. 
Juga untuk jenis penelitian lainnya, misalnya penelitian tindakan kelas, studi kasus, r\&d, dan mix method, metode penelitian harus disesuaian dengan jenis penelitian yang dipilih.

\section{HASIL DAN PEMBAHASAN}

\section{a. Waktu dan Tempat Penelitian}

Penelitian ini telah dilaksanakan mulai tanggal 28 Agustus 2017 sampai tanggal 28 September 2017. Pengumpulan data dibagi dalam 2 tahap. Tahap pertama adalah pengumpulan data sekunder mulai tanggal 28 Agustus 2017 sampai tanggal 15 September 2017 di beberapa instansi terkait yang masing-masing berada di Kelurahan Rewarangga Selatan, Kecamatan Ende Timur, Kabupaten Ende. Tahap kedua adalah pengumpulan data primer mulai tanggal 16 September 2017 sampai tanggal 28 September 2017 yang difokuskan pada lokasi petani/pembudidaya yang berada di wilayah Kelurahan Rewarangga Selatan, Kecamatan Ende Timur, yakni RT Jama Ipirowa RW Tana Li.

\section{b. Metode Penelitian}

Metode yang digunakan dalam penelitian ini adalah dengan menggunakan Metode Survei. Menurut Nazir (1988), metode survei adalah penyelidikan yang diadakan untuk memperoleh fakta-fakta dari gejala-gejala yang ada dan mencari keterangan-keterangan secara faktual, baik tentang institusi sosial, ekonomi, atau politik dari suatu kelompok ataupun suatu daerah. Dalam metode survei juga dikerjakan evaluasi serta perbandinganperbandingan terhadap hal-hal yang telah dikerjakan orang dalam menangani situasi atau masalah yang serupa dan hasilnya dapat digunakan dalam pembuatan rencana dan pengambilan keputusan.

\section{c. Jenis dan Sumber Data}

Data yang dikumpulkan dalam penelitian ini adalah jenis data primer dan data sekunder. Data sekunder diperoleh dari publikasi resmi yang dikeluarkan oleh instansi terkait seperti Dinas Kelautan dan Perikanan (DKP) Kabupaten Ende dan Badan Pusat Statistik (BPS) Kabupaten Ende. Data primer diperoleh dari hasil wawancara terhadap Petani atau Pembudidaya Ikan Nila (PIN) yang ada di Kelurahan Rewarangga Selatan, Kecamatan Ende Timur, serta beberapa pihak terkait yaitu pedagang, penjual pakan dan obat-obatan.

\section{d. Metode Pengambilan Sampel}

Penentuan sampel lokasi penelitian dilakukan secara purposive sampling yakni memilih secara pasti suatu tempat tertentu untuk dijadikan sebagai sampel penelitian. Sampel yang dipilih oleh peneliti di Kelurahan Rewarangga Selatan adalah RT Jama Ipirowa 
RW Tana Li. RT tersebut dipilih atas pertimbangan letaknya tidak jauh dari kota dan terdapat 5 unit kolam budidaya.

Penentuan sampel untuk mengumpulkan data primer dilakukan dengan menggunakan metode total sampling atau sensus. Metode sensus digunakan apabila dalam penelitian seluruh anggota populasi diambil sebagai sumber data. Metode ini berlaku jika anggota populasi relatif kecil dan relatif mudah dijangkau. Penggunaan metode pengambilan sampel ini diharapkan hasilnya dapat cenderung lebih mendekati nilai sesungguhnya dan dapat pula memperkecil kesalahan atau penyimpangan terhadap nilai populasi (Nazir, 1988). Dalam penelitian ini, jumlah populasi unit usaha budidaya ikan Nila relatif sedikit dan mudah dijangkau yaitu, ada 5 unit usaha budidaya ikan Nila yang ada di RT Jama Ipirowa, RW Tana Li, Kelurahan Rewarangga Selatan, Kecamatan Ende Timur. Responden yang dipilih berjumlah 5 orang.

\section{e. Analisis Kelayakan Finansial}

Analisis kelayakan usaha dilakukan untuk mengkaji kemungkinan keuntungan (profitability) atau kerugian yang diperoleh dari suatu usaha. Ada dua macam analisis yang digunakan untuk mengevaluasi kelayakan usaha, yaitu analisis finansial dan analisis ekonomi (Kadariah et al. 1999). Analisis kelayakan usaha dalam penelitian ini menggunakan analisis finansial yang meliputi analisis usaha dan analisis kriteria investasi.

\section{Analisis Usaha}

Menurut Hermanto (1989) dalam Laitupa (2013), komponen yang dipakai dalam melakukan analisis usaha meliputi biaya produksi, penerimaan usaha dan pendapatan yang diperoleh dari usaha perikanan. Terdapat beberapa analisis yang dilakukan dalam analisis usaha yaitu analisis keuntungan, analisis imbangan penerimaan dan biaya (Revenue Cost Ratio), analisis Payback Period (PP) dan analisis Return of Investment (ROI).

\section{Analisis Kriteria Investasi}

Analisis kriteria investasi yang dilakukan dalam penelitian ini yaitu analisis $\mathrm{Net}$ Present Value (NPV), Internal Rate of Return (IRR) dan Net Benefit Cost Ratio (Net $B / C$ ) (Kurniawati, 2005). Analisis ini dilakukan untuk mengetahui kelayakan usaha budidaya ikan Nila di Kelurahan Rewarangga Selatan, Kecamatan Ende Timur untuk waktu 5 tahun ke depan. 


\section{HASIL DAN PEMBAHASAN}

\section{Analisis Usaha Budidaya Ikan Nila}

\section{a. Analisis Keuntungan}

Analisis keuntungan dalam usaha budidaya ikan Nila dipengaruhi oleh total biaya yang digunakan dalam operasi budidaya serta total penerimaan yang diperoleh dari usaha budidaya tersebut. Keuntungan merupakan selisih antara penerimaan dan biaya.

\section{Biaya}

Total biaya yang dikeluarkan untuk setiap unit usaha budidaya ikan Nila dengan rata-rata sebesar $\mathrm{Rp}$ 74.426.000. Total biaya tersebut merupakan penjumlahan ratarata dari biaya investasi, biaya tetap dan biaya variabel. Dalam suatu usaha, biaya dibagi dalam beberapa kelompok. Sama halnya dalam usaha budidaya ikan Nila, biaya dibagi atas biaya investasi, biaya tetap (fixed cost), dan biaya tidak tetap (variable cost). Biaya investasi dalam usaha budidaya ikan Nila di Kelurahan Rewarangga Selatan, Kecamatan Ende Timur merupakan biaya yang dikeluarkan untuk pengadaan atau pembelian barang-barang investasi. Komponen biaya investasi dari usaha budidaya ikan Nila di Kelurahan Rewarangga Selatan terdiri dari pengadaan kolam, timbangan ikan, ember pakan, ember panen, alat pancing, genset. Total biaya investasi dengan rata-rata sebesar $\operatorname{Rp} 30.100 .000$. Biaya investasi rata-rata dari setiap unit usaha disajikan pada Tabel 1 .

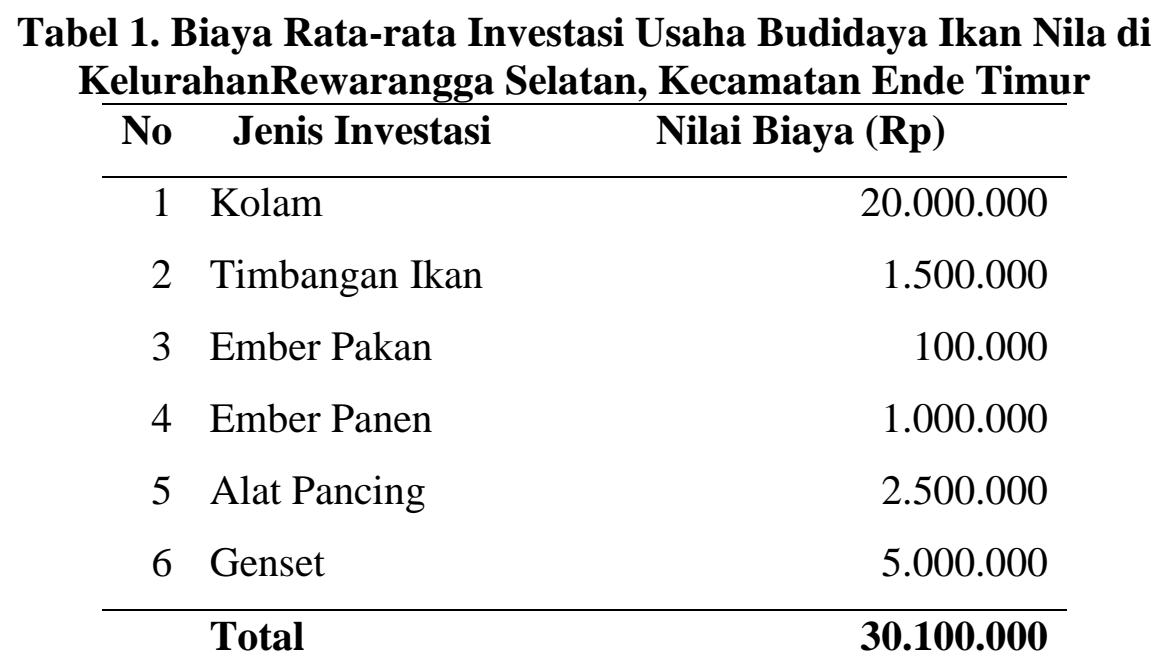

Total biaya tetap untuk usaha budidaya ikan Nila dengan rata-rata Rp 2.500.000. Komponen biaya tetap tersebut terdiri dari biaya perawatan kolam dan biaya perawatan genset. Biaya perawatan kolam dan genset merupakan 10\% dari nilai biaya investasi. Biaya perbaikan atau perawatan dikeluarkan setiap tahun juga dengan nilai 
biaya $10 \%$ dari nilai biaya investasi. Umumnya setiap kolam yang ada di Kelurahan Rewarangga Selatan, Kecamatan Ende Timur memiliki jangka waktu perbaikan atau perawatan yang hampir sama. Rincian biaya tetap rata-rata dari setiap unit usaha budidaya ikan Nila di Kelurahan Rewarangga Selatan, Kecamatan Ende Timur dapat dilihat pada Tabel 2 .

Tabel 2.Biaya Tetap Rata-rata Usaha Budidaya Ikan Nila di Kelurahan
\begin{tabular}{rlr} 
Rewarangga Selatan, Kecamatan Ende Timur \\
\cline { 2 - 3 } No & Jenis Biaya Tetap & Nilai Biaya (Rp) \\
\hline 1 & Perawatan Kolam & 2.000 .000 \\
2 & Perawatan Genset & 500.000 \\
\hline \multirow{2}{*}{ Total } & 2.500 .000
\end{tabular}

Total biaya variabel untuk usaha budidaya ikan Nila di Kelurahan Rewarangga Selatan, Kecamatan Ende Timur dengan rata-rata Rp 41.826.000. Adapun komponen biaya variabel adalah biaya untuk kebutuhan bahan bakar genset, pakan, benih ikan dan upah tenaga kerja. Biaya variabel rata-rata untuk setiap unit usaha budidaya ikan Nila disajikan pada Tabel 3.

Tabel 3. Biaya Variabel Rata-rata Usaha Budidaya Ikan Nila di Kelurahan Rewarangga Selatan, Kecamatan Ende Timur

\begin{tabular}{|c|c|c|c|c|c|c|}
\hline \multirow{2}{*}{$\begin{array}{c}\text { No } \\
\text { Resp }\end{array}$} & \multicolumn{5}{|c|}{ Jenis Biaya Tidak Tetap (Rp/Tahun) } & \multirow{2}{*}{ Total } \\
\hline & Benih & Pakan & Tenaga Kerja & BBM & Oli & \\
\hline 1 & 6.000 .000 & 1.800 .000 & 28.800 .000 & 1.596 .000 & 210.000 & 38.406 .000 \\
\hline 2 & 7.500 .000 & 3.000 .000 & 28.800 .000 & 1.596 .000 & 210.000 & 41.106 .000 \\
\hline 3 & 10.500 .000 & 4.200 .000 & 28.800 .000 & 1.596 .000 & 210.000 & 45.306 .000 \\
\hline 4 & 7.500 .000 & 3.000 .000 & 28.800 .000 & 1.596 .000 & 210.000 & 41.106 .000 \\
\hline 5 & 9.000 .000 & 3.600 .000 & 28.800 .000 & 1.596 .000 & 210.000 & 43.206 .000 \\
\hline $\begin{array}{l}\text { Rata- } \\
\text { rata }\end{array}$ & 8.100 .000 & 3.120 .000 & 28.800 .000 & 1.596 .000 & 210.000 & 41.826 .000 \\
\hline
\end{tabular}

Nilai pengadaan benih berbeda karena masing-masing responden memiliki luas kolam yang berbeda. Hal ini juga berpengaruh terhadap kebutuhan pakan sehingga nilai pakan juga berbeda. Rata-rata penggunaan bahan bakar dan pelumas untuk mesin tambahan (Genset) dari setiap unit kolam yang ada di Rewarangga Selatan, Kecamatan Ende Timur adalah sama untuk setiap periode budidaya. Jumlah penggunaan bahan 
bakar ini akanbertambah sejalan dengan semakin sering terjadi pemadaman listrik. Upah tenaga kerja masing-masing responden memiliki nilai yang sama.

\section{Penerimaan}

Penerimaan setiap unit usaha budidaya ikan Nila tahun 2016 dengan rata-rata Rp 105.518.400. Penerimaan usaha budidaya ikan Nila di Kelurahan Rewarangga Selatan, Kecamatan Ende Timur diperoleh dari hasil penjualan seluruh produksi yang dihasilkan dikali harga jual ikan per kilogram. Harga jual produksi hasil budidaya ini tetap sama untuk setiap periode budidaya yaitu Rp 40.000 per kg dengan jumlah ikan 3-4 ekor perkg. Produksi, harga jual dan penerimaaan dalam tahun 2016 disajikan pada Tabel 4.

Tabel 4. Produksi, Harga Jual dan Penerimaan Usaha Budidaya Ikan Nila dalam Tahun 2016 di Kelurahan Rewarangga Selatan, Kecamatan Ende Timur

\begin{tabular}{lccc}
\hline \multicolumn{1}{c}{ Bulan } & Jumlah Produksi (Kg) & Harga Jual (Rp/Kg) & $\begin{array}{c}\text { Penerimaan } \\
(\mathbf{R p})\end{array}$ \\
\hline Januari & 219.83 & 40.000 & 8.793 .200 \\
Februari & 219.83 & 40.000 & 8.793 .200 \\
Maret & 219.83 & 40.000 & 8.793 .200 \\
April & 219.83 & 40.000 & 8.793 .200 \\
Mei & 219.83 & 40.000 & 8.793 .200 \\
Juni & 219.83 & 40.000 & 8.793 .200 \\
Juli & 219.83 & 40.000 & 8.793 .200 \\
Agustus & 219.83 & 40.000 & 8.793 .200 \\
September & 219.83 & 40.000 & 8.793 .200 \\
Oktober & 219.83 & 40.000 & 8.793 .200 \\
November & 219.83 & 40.000 & 8.793 .200 \\
Desember & 219.83 & 40.000 & 8.793 .200 \\
\hline Total & 2.638 & & 105.518 .400 \\
\hline
\end{tabular}

Berdasarkan rincian total biaya yang dikeluarkan dan total penerimaan yang diperoleh dalam usaha budidaya ikan Nila di Kelurahan Rewarangga Selatan, Kecamatan Ende Timur, maka dapat diketahui berapa besar keuntungan yang diperoleh oleh pemilik unit kolam budidaya ikan Nila. Keuntungan diperoleh dari pengurangan total penerimaan sebesar Rp 105.518.400 dengan total biaya yang dikeluarkan sebesar Rp 44.326.000. Dengan demikian diketahuilah bahwa keuntungan usaha budidaya ikan Nila di Kelurahan Rewarangga Selatan, Kecamatan Ende Timur untuk jangka waktu satu tahun sebesar Rp 61.192.400. 


\section{b. Analisis Imbangan Penerimaan dan Biaya (R/C)}

Analisis $R / C$ dilakukan untuk mengetahui seberapa jauh setiap nilai rupiah biaya yang dikeluarkan dalam kegiatan usaha dapat memberikan sejumlah nilai penerimaan sebagai manfaat (Laitupa, 2013), atau sebaliknya untuk mengetahui seberapa besar penerimaan yang diperoleh dari setiap nilai rupiah biaya yang dikeluarkan pada usaha Budidaya ikan Nila di Kelurahan Rewarangga Selatan, Kecamatan Ende Timur. Nilai $R / C$ diperoleh dengan membandingkan total penerimaan sebesar Rp 105.518.400 dengan total biaya yang dikeluarkan sebesar Rp 44.326.000.

Berdasarkan hasil analisis diketahui bahwa kegiatan usaha budidaya ikan Nila mendapatkan keuntungan dengan imbangan penerimaan dan biaya $(R / C)$ sebesar 2,38. Angka tersebut dapat diartikan bahwa setiap rupiah total biaya yang dikeluarkan untuk usaha budidaya ikan Nila tersebut akan menghasilkan total penerimaan sebesar Rp 2,38 .

\section{c. Analisis Payback Period (PP)}

Menurut Suyanto (2004), payback period (PP) adalah waktu yang diperlukan oleh suatu usaha untuk mengembalikan jumlah dana yang telah diinvestasikan dalam usaha tersebut, dalam hal ini adalah usaha budidaya ikan Nila di Kelurahan Rewarangga Selatan, Kecamatan Ende Timur. Disebutkan pula bahwa apabila waktu pengembalian investasi lebih cepat, maka usaha ini pun semakin baik.

Hasil analisis PP untuk usaha budidaya ikan Nila ini sebesar 0,49 tahun. Hal ini berarti bahwa rata-rata waktu yang diperlukan untuk mengembalikan dana yang telah diinvestasikan pada usaha budidaya ika Nila di Kelurahan Rewarangga Selatan Kecamatan Ende Timur adalah 0,49 tahun atau 5 bulan dan 29 hari.

\section{d. Analisis Return of Investment (ROI)}

Analisis ROI bertujuan untuk mengetahui seberapa besar tingkat keuntungan yang diperoleh dalam setiap rupiah investasi yang dikeluarkan pada awal usaha budidaya ikan Nila di Kelurahan Rewarangga Selatan, Kecamatan Ende Timur. ROI merupakan perbandingan antara nilai keuntungan yang diperoleh sebesar $\mathrm{Rp}$ 61.192.400 dan nilai investasi yang dikeluarkan pada awal usaha sebesar Rp 30.100.000, dimana ROI dinyatakan dalam bentuk persentase.

Hasil analisis ROI menunjukkan bahwakemampuan investasi dalam usaha budidaya ikan Nila untuk menghasilkan keuntungan bersih sebesar 203,30. Hasil tersebut memiliki arti bahwa setiap rupiah yang diinvestasikan pada usaha budidaya ikan Nila tersebut akan memberikan keuntungan rata-rata sebesar 203,30\%. 


\section{Analisis Kriteria Investasi Usaha Budidaya Ikan Nila}

a. Net Present Value (NPV)

Dalam perhitungan nilai $N P V$ menggunakan nilai discount rate, yang dalam penelitian ini menggunakan nilai discount rate sebesar 17\%. Dari hasil analisis diketahui nilai $N P V$ usaha budidaya ikan Nila sebesar Rp 161.185.453 Nilai ini berarti bahwa usaha budidaya ikan Nila tersebut akan memberikan rata-rata net benefit sebesar Rp 161.185.453 selama umur usaha 5 tahun dengan discount rate sebesar $17 \%$ per tahun.

\section{b. Internal Rate of Return (IRR)}

Nilai IRR dari usaha budidaya ikan Nila di Kelurahan Rewarangga Selatan, Kecamatan Ende Timur adalah sebesar 2,02\% yang berada di bawah nilai discount rate 17\%. Hal ini menunjukkan bahwa usaha budidaya ikan Nila tersebut tidak memberikan manfaat yang baik dari nilai investasi yang ditanamkan rata-rata sebesar 2,02\% tiap tahunnya selama umur usaha 5 tahun. Tetapi hal ini tidak memberikan pengaruh negatif terhadap nilai keutungan secara keseluruhan dari usaha tersebut, sebab hanya satu unsur yaitu IRR saja yang tidak memenuhi kriteria.

\section{c. Net Benefit Cost Ratio (Net B/C)}

Nilai Net $B / C$ usaha budidaya ikan Nila di Kelurahan Rewarangga Selatan, Kecamatan Ende Timur adalah sebesar 6,35. Nilai ini memiliki arti bahwa setiap satu rupiah biaya yang dikeluarkan akan menghasilkan rata-rata keuntungan bersih sebesar Rp 6,35 selama 5 tahun dengan nilai discount rate $17 \%$.

Hasil perhitungan dalam analisis kriteria investasi menunjukkan bahwa usaha budidaya ikan Nila merupakan usaha yang layak dikembangkan dengan nilai NPV> 0, IRR $<$ discount rate $17 \%$ dan Net $\mathrm{B} / \mathrm{C}>1$.

\section{KESIMPULAN}

Usaha budidaya ikan Nila (Oreochromis niloticus) dengan menggunakan sistim semi intensif di Kelurahan Rewarangga Selatan, Kecamatan Ende Timur memberikan keuntungan sebesar Rp 61.192.400 dengan imbangan penerimaan dan biaya sebesar 2,38. Waktu yang diperlukan untuk mengembalikan dana yang telah diinvestasikan yaitu selama 0,49 tahun. Kemampuan modal dalam usaha budidaya ikan Nila untuk menghasilkan keuntungan bersih adalah sebesar 203\%. Usaha budidaya ikan Nila merupakan usaha yang layak dikembangkan 
karena memiliki nilai NPV > 0 yaitu sebesar Rp 161.185.453, nilai IRR < tingkat suku bunga $17 \%$ yaitu sebesar $2,02 \%$ dan Net B/C > 1 yaitu sebesar 6,35.

\section{DAFTAR PUSTAKA}

[BPS] Badan Pusat Statistik Kabupaten Ende. 2016. Ende dalam Angka. Perkembangan Produksi Hasil Perikanan di Kabupaten Ende.

Darseno. 2010. Buku Pintar Budidaya dan Bisnis Nila. Agromedia Pustaka Jakarta.

Fauzi A dan Anna S. 2005. Pemodelan Sumberdaya Perikanan dan Kelautan untuk Analisis Kebijakan. Jakarta: Gramedia Pustaka Utama.

Kadariah, L Karlina dan C Gray. 1999. Pengantar Evaluasi Proyek. Jakarta: Lembaga Penerbit Fakultas Ekonomi Universitas Indonesia.

Kurniawati. 2005. Optimisasi Pengembangan Perikanan Purse Seine di PPN Pemangkat Kabupaten Sambas, Provinsi Kalimantan Barat. [Tesis]. Institut Pertanian Bogor.

Laitupa, J.P. 2013. Strategi Pengelolaan Perikanan Tuna Secara Optimal dan Berkelanjutan di Kabupaten Buru Provinsi Maluku [Tesis]. Institut Pertanian Bogor. 126 Hal.

Meriza,Y. 2008. Analisis Finansial Usaha Budidaya Ikan Nila Di Nagari Koto Kaciak, Kecamatan Tanjung Raya, Kabupaten Agam, Provinsi Sumatera Barat. [Skripsi]. Faperikan Unri. Pekan Baru. 83 halaman.

Murtidjo, K.B.A. 2007). Pedoman Meramu Pakan Ikan. Jakarta: Penerbit Kanisius.

Nazir, M. 1988. Metode Penelitian. Jakarta: Ghalia Indonesia.

Nugroho, E. 2007. Kiat Agribisnis Nila. Jakarta: Penebar Swadaya.

Rachmatun, S. 2011. Pembenihan dan Pembesaran Nila. Depok, Jakarta: Penebar Swadaya.

Suyanto, R. 2004. Budidaya Ikan Nila. Jakarta: Penebar Swadaya. 